\title{
Kazakh Perspective on China, Chinese and Chinese Migration
}

\author{
Burkhanov , Aziz
}

Routledge

2017-05

Burkhanov , A \& Chen , Y-W 2017 , Kazakh Perspective on China, Chinese and Chinese

Migration . in M Dillon (ed.), Chinese Minorities at Home and Abroad . Routledge, London .

http://hdl.handle.net/10138/328247

acceptedVersion

Downloaded from Helda, University of Helsinki institutional repository.

This is an electronic reprint of the original article.

This reprint may differ from the original in pagination and typographic detail.

Please cite the original version. 


\title{
Kazakh Perspective on China, the Chinese, and Chinese Migration
}

\author{
Aziz Burkhanov ${ }^{1}$ and Yu-Wen Chen \\ Graduate School of Public Policy, Nazarbayev University, Astana, Kazakhstan \\ Department of World Cultures, University of Helsinki, Helsinki, Finland and \\ Department of Asian Studies, Palacky University, Olomouc, Czech Republic
}

\begin{abstract}
Discourse analysis of different languages of newspapers in Kazakhstan reveals that Kazakhstanis' views toward China and the Chinese are divided. The official discourse in both state-sponsored Russian and Kazakh newspapers is in accordance with the country's policy toward further engagement with their rising Chinese neighbor. However, negative stereotypes of China and the Chinese, as well as sinophobia, are pervasive in private Kazakh language newspapers. Private Russian newspapers have a more nuanced view toward China, with a hidden inclination toward being critical of that country and its people. Although the majority of these societal voices do not have a direct impact on changing the national policies of Kazakhstan, they are important in the sense that Kazakhstan's ruling elite must continue to gauge social views and to placate differences in order to secure the stability and legitimacy of the regime.
\end{abstract}

Keywords: Kazakhstan, discourse analysis, China, Chinese, stereotype, sinophobia.

\section{Introduction}

Since the new post-Soviet states emerged in Central Asia in 1991, China has been seeking to foster diplomatic, political, and economic relations with these new territories (Schoen and Kaylan 2014; Clarke 2011). The official lines of Central Asian states are also moving toward benign relations with their growing Chinese neighbor. However, Laruelle and Peyrouse (2012) noted that the Central Asian populace does not look on Beijing's inroads into the region as favorably as do official discourses from Central Asian governments. The crux of this analysis lies in delving into this local perspective. The country under investigation is Kazakhstan, which is a good

\footnotetext{
${ }^{1}$ Aziz Burkhanov, Aziz.Burkhanov@nu.edu.kz

Yu-Wen Chen, Yu-Wen.Chen@upol.cz
} 
starting point for examination because it is geographically close to China. As the country is normally considered a leading player in Central Asia, an assessment of how its populace perceives China and the Chinese would provide an indication of how other Central Asians respond to their rising powerful neighbor.

Another factor that makes Kazakhstan an interesting case for analysis is that the country is ethnically diverse. It is undergoing the process of nation-building, with significant ethnic minorities having presence in Kazakhstan, and two languages, that is, Kazakh and Russian, being widely used in the media and everyday life (Spehr and Kassenova 2012; Burkhanov and Sharipova 2014). In a similar manner to other Central Asian countries, Kazakhstani society is seeking a way to define its national identity. It is a daunting task, as the Kazakh national patriots and Russian nationalist groups have apparently different interests in this nation-building process (Zardykhan 2004; Bremmer 1994; Brubaker 2011; Yemelianova 2014). The stability of the country and the legitimacy of the ruling elite will ultimately be affected by whether the regime can find a way to appeal to these two strikingly different groups. The aim of our analysis was to understand different views and narratives that exist in the country with regard to an increasingly salient 'other', that is, the rising Chinese neighbor, as well as the Chinese in Kazakhstani society.

There follows an overview of Kazakhstan's increasing ties with China, and then our conceptual basis which borrows from various international findings on how the media serves as a source of public debate in general and in Kazakhstan specifically. In the methodology section, we explain how we selected and used discourse analysis to examine the stances of different newspapers (public vs. private; Russian vs. Kazakh) with regard to their Chinese neighbor and the Chinese inside Kazakhstan. The second last part of this paper presents the empirical findings and our conclusions are drawn in the final section.

\section{Sino-Kazakhstani Relations}

At the state level, both Beijing and Astana believe that fostering relations is beneficial. Economically, China needs Kazakhstan to supply the raw materials and natural resources (e.g., hydrocarbons, oil, gas, minerals) that it requires for its own development, while, in turn, Kazakhstan needs basic consumer goods and finished products from China (Shambaugh and Yahuda 2008; O'Neill 2014). In the domain of 
regional security, both China and Central Asia are aware of the advantages of cooperation to strengthen their borders and to prevent any separatist or extremist movements (e.g., those originating from the Uyghurs) from developing and multiplying (Chen 2014).

As a result of China's interest in Central Asia, Beijing has developed a Central Asia policy with emphasis on peace, cooperation and development. From the more security-oriented Shanghai Cooperation Organization (SCO) to the most recent Silk Road Economic Belt initiative, China stresses that there is equality among participating countries and the cooperative efforts are supposed to result in mutual benefits. ${ }^{1}$ China does not want its efforts to be interpreted as the creation of a new great game nor its ambition to generate new sphere of influence in Central Asia.

Despite China's disclaimer of its ambitions in Central Asia, most observers do see the rising competition of great powers in the region (Ziegler, and Menon 2014; Clarke 2008). This is in line with numerous discussions, in academia as well as in public debate, regarding whether the ascent of China poses threats or could bring peace to world politics (Mearsheimer 2010; Aldrich, Lu, and Liu 2014; Chu, Kang, and Huang 2014; Kang and Chu 2014). Different countries have reacted to this challenge in a variety of ways. Some have contended that East Asian and Southeast Asian countries are neither balancing nor bandwagoning against China (Cheng and Hsu 2005; Kuik 2008; Kang 2009). Rather, they have tried to keep all strategic options open, allowing the possibility of including both elements of balancing and bandwagoning in coping with their relations with that country. This is exemplified in the way Kazakhstan addresses relations with China as well.

More specifically, Kazakhstan has a so-called 'multi-vector' foreign policy that is not only aimed at tackling the challenge of the rise of China, but also at helping Kazakhstan cope with the ever-challenging international environment on various fronts. Kazakhstan is a massive country in terms of size, but a relatively small power when it comes to other indicators, such as economic power and political clout. Due to geographic vicinity, the presence of large Kazakh minority in China's Xinjiang as well as the large Uyghur population in Kazakhstan, China has always had a place in Kazakhstan's foreign policy (Clarke 2014).

Kazakhstan, however, is not only close to China. It is also near Russia and has traditionally been influenced by Russia. Neighboring two giants makes the ruling elite aware of the necessity of striking a balanced relationship with its giant neighbors, 
while still maintaining its own sovereignty. The multi-vector foreign policy serves this purpose, as well as helping to signal to countries around the world that Kazakhstan is on good terms with many nations, raising its stance and image in world politics (Chen 2015).

In addition to serving Kazakhstan's external interests, the multi-vector foreign policy has the merit of speaking to domestic constituents (Clarke 2014; Burkhanov and Sharipova 2014), which is clearly exhibited in Kazakhstan's relationship with China (Clarke 2014). In order to help maintain its legitimacy in governing the country, ${ }^{2}$ the ruling elite have used the multi-vector policy to avoid blame and to take credit. When the public is supportive of a certain government undertaking with China, the government triumphantly proclaims this as an achievement of its multi-vector policy with regard to establishing a good relationship with Beijing. Conversely, when society is not satisfied with the government's handling of certain issues with China, such as the 2008-2009 controversy over Kazakhstan's lease of a massive swathe of land to that neighbor, the government avoided blame by arguing that it never attempted to favor any other countries at the cost of Kazakhstan's interests (Chen 2015).

A review of the current literature shows that Central Asians, including those in Kazakhstan, generally do not necessarily see eye-to-eye with their leaders' gradual prioritization of improving relations with China (Laruelle and Peyrouse 2012). Survey analysis and some expert observations have indicated the existence of phobias and myths when it comes to Kazakhstani citizens' perceptions of China and the Chinese people. For example, there are fears regarding the growing Chinese migration to Kazakhstan, and the wage gap between Chinese and local laborers in the industries of local infrastructure arouse great resentment. The Chinese are viewed as taking away locals' jobs. The influx of Chinese goods into Kazakhstan is also perceived as a threat to local products. Part of this antagonism is supported by facts (Sadovskaya 2007; Syroezhkin 2009). However, Syroezhkin (2009 and 2014) cautioned that some of the problems have been dramatized and exaggerated. The lack of accurate and sober understanding of China and Sino-Kazakhstani relations breeds stereotypes, sinophobia, and myths. Even at the expert level, there is a paucity of researchers who are studying contemporary China and who are capable of offering impartial views on that country and its people, as well as an absence of expert views on the specificities of Sino-Kazakhstani relations (Clarke 2014; Syroezhkin 2009 and 2014). 
Although they are few in number, some studies have revealed a regional difference in local perceptions. For example, the residents of Almaty, which is the old political and administrative capital of Kazakhstan, and which has a longer history of exchanges with China, show a greater knowledge of that country than do residents in other parts of the country (Syroezhkin 2009). In Central and Western regions of Kazakhstan, awareness of Chinese culture, history, and traditions is the lowest, compared to other areas of the country (Sadovskaya 2007; Syroezhkin 2009). It has also been found that the public is more interested in economic development, foreign policy, and sociodemographic issues in China than in Chinese culture. This reflects the fact that issues that concern citizens in Kazakhstan are more practically oriented (Syroezhkin 2009).

We delved into this perceptual difference by discerning the views stated in Russian and Kazakh newspapers. These newspapers have different target audiences, and represent the views of different ethnic groups in the country. As noted previously, the ruling elite in Kazakhstan has an interest in consolidating its ruling legitimacy. On one level, they must find a way to satisfy and balance the needs of the ethnic Russians and Kazakh nationalists whose divergent views could tear the country apart. Addition of the China factor complicates the task, because the regime's growing ties with China, for apparently important national interests, are not necessarily well-received at the public level. We employed discourse analysis of newspapers of different languages to reveal the narratives that different sectors of Kazakh society have been weaving, accepting, and debating, with regard to China and the Chinese people. In the next section, we clarify why we used the media, that is, the newspapers, to gauge perceptual differences in Kazakhstan.

\section{Media as Sources of Discourses}

Since Kazakhstan gained independence, its number of media outlets has grown dramatically. In the late 1980s, the total number of registered media outlets was only ten republic-level printed media and twenty-one TV and radio channels. In 2012, the total number of registered media outlets at all levels was 2,765, including 1,619 newspapers and 848 magazines (MediaLaw Internews Project 2010; Ministry of Culture and Information Statistics 2012). The state versus non-state media ownership breakdown demonstrates that the state remains not only a regulator, but also a significant player in the media market. Of the 2,765 registered media outlets in 2012 , 
439 (16 per cent) were owned by the state and 2,326 (84 per cent) were privately owned. Printed media accounted for over ninety percent of the total number of registered media outlets, including the 1,619 newspapers, among which 328 (20 per cent) are owned by the state, and 1,291 ( 80 per cent) are privately owned. Of the 848 magazines, 636 (79 per cent) are privately owned and 172 (21 per cent) are stateowned. Language breakdown statistics show that in May 2013, 344 media outlets operated in only Kazakh, 758 in only Russian, 727 in both Kazakh and Russian, and 282 in Kazakh, Russian, and other languages. Approximately thirty-three printed media outlets were published in fifteen different languages of various ethnic groups of Kazakhstan. However, these numbers do not necessarily mean that all of these media outlets actually operate actively in the market - in certain cases they are technically registered, but have been put in a 'sleeping mode' to be activated and used in the future; in addition, this number includes a significant number of papers that have been created only to print private advertisements. However, despite the massive privatization campaign of the media outlets in the early 1990s, and the fact that, unlike in the Soviet era, newspapers can benefit from advertisements, sales, and subscription incomes in the post-independence period, most newspapers in Kazakhstan are not profitable or financially self-sufficient. Rather, they depend on patron state agencies or private owners to finance their operations (Junisbai 2011).

The media in Kazakhstan has a lot in common with the Soviet press-where the media were not expected to inform the audience about current events, but instead, were used to transmit ideological messages from the Communist party. Another important similarity is the lack of connection with the market imperatives. In the Soviet Union, newspapers had guaranteed funding from the State and never had to worry about profits or finances - something we see replicating in today's Kazakhstan. Most media outlets are not profitable and depend on their sponsors and parent companies on funding. ${ }^{3}$

As various studies have shown (Wanta, Golan, and Lee 2004; Maxwell and Shaw 1972), the media in general in various parts of the world have the capability to 'set the agenda' for domestic and international politics. They not only inform the audience of politically salient issues, but also influence readers' evaluations of these issues by interpreting news in a positive or negative fashion. In ethnically diverse and multilingual societies, the media can also reflect different perceptions, prejudices, and stereotypes that various ethnic groups possess or express about one another, as well as 
about neighboring countries, and thus contribute to the perception of these nations that is held by mass audiences. It is with this in mind that we decided to use discourse analysis to study newspapers in Kazakhstan.

\section{Newspapers Studied and Their Readers}

Four of Kazakhstan's nationwide print newspapers with the largest circulation size were chosen for examination: Egemen Qazaqstan [Independent Kazakhstan] and Zhas Alash [Young Alash] printed in Kazakh, and Kazakhstanskaia Pravda [Truth of Kazakhstan] and Vremia [Time] published in Russian. Kazakhstanskaia Pravda and Egemen Qazaqstan are two major government-owned nationwide newspapers that are used to express the regime's officially sanctioned view on major political and social issues in Kazakhstan. They were both founded in the early 1920s, and for a long time were the official organs of the Communist Party of the Kazakh Soviet Socialist Republic. In independent Kazakhstan, they have continued the decades-long Soviet tradition of the pro-government newspapers; however, after the collapse of the Soviet Union, they did adjust their practices in order to appear more like genuine newspapers and not just propaganda organs of the Communist Party. Their audiences consist primarily of public servants working at government agencies, regional and municipal administrations, and the so-called biudzhetniki; employees of state-funded institutions, such as public hospitals and high schools. In 2011, circulation of Kazakhstanskaia Pravda was estimated at approximately 100,000 copies, with a corresponding figure of 170,000 copies for Egemen Qazaqstan.

The Russian-language official paper tends to represent direct governmental views. Relatively speaking, the Kazakh-language official paper can maintain more critical distance and take more critical positions vis-à-vis the government policies than the Russian-language official paper.

The Russian-language Vremia and the Kazakh-language Zhas Alash represent another segment of the newspaper market of Kazakhstan. These newspapers are technically privately owned (although Vremia is technically owned by an industrial group indirectly affiliated with the government) and, as such, are far less limited by governmental discourse. They often take contrasting positions in their coverage of political and social issues, compared with Kazakhstanskaia Pravda and Egemen Qazaqstan. Zhas Alash, known as Leninshil Zhas [Leninist Youth] in the Soviet era, is 
sympathetic toward the Kazakh-speaking intelligentsia in its editorial policies, including those intellectuals with rather nationalist views; its circulation size is estimated at approximately 50,000 copies. Vremia inherited most of the journalists and concepts from Karavan, a famous and extremely popular newspaper of the 1990s. After Karavan expressed harsh criticism of the regime, owner Boris Gillner was forced to sell the newspaper and emigrate; the entire journalist staff left the paper in protest and started Vremia. Although it is under the patronage of the state-owned corporation, Kazakhmys, the paper has managed to preserve its quasi-independent editorial policies. Its circulation is approximately 180,000 for the weekly edition, and around 30,000 for the daily edition, making it by far the most popular private newspaper in the country.

Kazakhstan has a complicated language situation, which has political, social, economic, and cultural implications, and which also affects newspaper readership. The language issue is one of the most sensitive factors in domestic policy in postindependence Kazakhstan. Russian gradually became the dominant language in Kazakhstan over the course of the Soviet era, due to a massive campaign of Russification. Schools and universities adopted Russian as the language of instruction, and, although the Russian-language schools of Kazakhstan offered Kazakh language lessons, most students did not take this requirement seriously. Pupils usually graduated from schools with no, or very minimal, knowledge of Kazakh, and felt no need to improve it. In contrast, as Russian was necessary to secure a successful career in Soviet society, most urban Kazakhs learned in Russian schools, kindergartens, and universities and came to use Russian as their principal means of communication. Kazakh was granted state language status only by Language Law 24 of 1989, which was an important symbolic marker, although limited efforts were made in terms of its implementation (Fierman 1998).

After independence, the 1993 Constitution of Kazakhstan confirmed the status of Kazakh as the state language and Russian as a language of interethnic communication. However, in 1995, the new Constitution amended this situation and, while continuing to grant Kazakh the status of the only state language, it also allowed Russian to be used officially on an equal basis in state agencies. In practice, implementation of stricter Kazakh language policies, although officially declared, has faced a number of problems, mainly due to lack of resources and inefficient policies. Measures aimed at enhancing usage of the Kazakh language have frequently been 
used as a justification for silencing oppositional media, mainly printed in Russian. In other cases, the media only formally comply with the legal requirements by broadcasting in Kazakh late at night and filling the Kazakh-language segment with low quality music video clips and movies from the Soviet era. Fluency in the Kazakh language remains limited among Russians and other ethnic groups of Kazakhstan. As some observers have argued (Zardykhan 2004; Bremmer 1994; Burkhanov and Sharipova 2014), for the Russians, it is probably a psychological factor that is the most significant barrier with regard to studying the Kazakh language. During the Soviet era, most Russians perceived Russian as being superior to Kazakh and now find themselves in the reverse situation; having to learn the language they have long considered as being inferior. They perceive the state promotion of the Kazakh language as unfair toward Russian and Russian-speakers, and some have appealed for Russian to be granted the status of the second state language. In contrast, Kazakh nationalist groups continue to criticize the government for not being sufficiently persistent in making Kazakh the genuine de facto state language, and view this as another manifestation of a colonial mentality and disrespect for Kazakh culture and language (Zardykhan 2004; Bremmer 1994; Burkhanov and Sharipova 2014).

The language distribution logically affects the audiences of the newspapers studied. As many observers have pointed out (Zardykhan 2004; Bremmer 1994; Brubaker 2011; Burkhanov and Sharipova 2014), the linguistic composition divides modern Kazakhstan society into two major groups with two distinctly different visions regarding the path that Kazakhstan should take to build its country. The first group includes so-called 'cosmopolitans', the urbanized and predominantly Russianspeaking population, who constitute the majority of the Kazakhstanskaia Pravda and Vremia audiences; the second group is the Kazakh-speaking 'ethnonationalists,' who prefer to read Egemen Qazaqstan and Zhas Alash. As Surucu asserted (2005), this division cuts sharply across ethnic boundaries and extrapolates further to the attitude toward modernization and vision of the state, with the ultimate question of what kind of modernization path Kazakhstan should follow. The 'cosmopolitans' deny Kazakh traditionalism, as they consider it backward and 'un-modern', and tend to orient to the examples of Western countries or Russia. Most of the members of this group have received their education in Russian-language schools and universities, and use Russian as their primary channel of communication; they live primarily in urban areas, such as Almaty, Astana, and oblast [regional] centers. 
In contrast, Kazakh-speaking 'ethnonationalists', who make up the bulk of the Egemen Qazaqstan and Zhas Alash audiences, tend to focus on national consolidation and the renaissance of the Kazakhs. From their perspective, modern Kazakhstan is a statehood of ethnic Kazakhs, built on the historical legacy of khans [rulers], batyrs [warriors], and biis [judges] of the historical Kazakh Khanate and traditional nomadic Kazakh culture. Most of the members of this group are Kazakh-speaking Kazakhs who were educated in Kazakh-language high schools, predominantly in rural areas, and who later migrated to urban areas, seeking better opportunities. The fact that many of these people have left mostly Kazakh-populated rural areas suffering from economic depression, to go to more prosperous and ethnically diverse cities, has led them to develop a sense that Kazakhs are underprivileged in their own country. There is almost no interaction between the two linguistic realms, it happens only rarely; Kazakh-language newspapers follow Russian-language publications and respond to them on their own pages. The Russian discourse practically ignores the Kazakhlanguage segment, due to the lack of Kazakh proficiency and because readers of Russian-language papers find those in Kazakh uninteresting and as focusing only on praising Kazakh culture and the glorious Kazakh heroes of the past.

Within the scope of this project, we seek to understand how the discourses related to Kazakh and Russian identities circulated in contemporary Kazakhstani society would limit how people in Kazakhstan see the Chinese 'other'. Our approach is inspired by Laclau and Mouffe's (2001) discourse analysis. It is different from critical discourse analysis that would require a more detailed analysis of linguistic practices to allow the exploration of power relationship, and in particular inequalities and power abuses revealed in the studied texts.

The articles selected for analysis in this study were printed in these newspapers between August 2013 and January 2015. They present a variety of genres, including interviews, news reports, reportages, open letters, op-ed columns, editorials, and readers' letters. The Kazakh press especially tends to include more interpretative articles with rather strong opinions rather than just representing news in a neutral tone.

In September 2013, the Chinese leader Xi Jingping visited Kazakhstan and gave a speech at Nazarbayev University, which was founded on the initiative and endorsement of the Kazakhstani president. In that speech, President Xi proposed that China and Central Asia should cooperate in building a Silk Road Economic Belt, 
leading observers to believe that China's relations with its Central Asian neighbor had reached a culmination. We intend to examine whether this visit by the Chinese president has changed newspapers' discourse on China and the Chinese. It is in this vein that most articles under analysis are between August 2013 (before Xi's visit) and January 2015 (the time we finished writing this paper).

\section{Empirical Findings and Discussions}

We found that the discourses presented in the newspapers studied do not much differ between before and after President Xi's visit to Kazakhstan in September 2013. However, variations do occur between newspapers. As Table 1 summarizes, statesponsored newspapers tend to have a positive view of Chinese-Kazakh relations, China, and the Chinese people, while private newspapers show diverse views, with a tendency to be skeptical toward China and the Chinese. Kazakh-language private newspapers exhibit the most hostility toward China. The display of negative and stereotypical images of China and its people is pervasive, demonstrating strong fear and antagonism. The Russian-language private newspaper is often read by conservative businessmen, and, while the discourse regarding China and the Chinese is also somewhat negative, it is frequently less directly expressed.

\section{[Table 1 to be inserted here]}

As politics, economics and the issue of Chinese people in Kazakhstan have been noted by scholars as key areas of discussions in the country (Syroezhkin 2009; Clarke 2014), the following sub-sections present newspaper discussions on these three topics and lead us to identify the way in which China and the Chinese people, as the 'others' are constructed in the media discourse, and therefore in the minds of the citizens of Kazakhstan.

\section{Political Cooperation with China}

Political cooperation was very frequently discussed in the newspapers, and was mostly described in a neutral-positive tone. With the exception of the Kazakh nationalist Zhas Alash newspaper, all other newspapers studied described cooperation projects and exchanges between the leadership of the two countries from a rather 
positive perspective. As the flagship government-backed newspaper, Kazakhstanskaia Pravda offered a particular example of a very positive interpretation of the Kazakhstani-Chinese relationship. The paper emphasized the close personal relationship between the leaders of the two countries as being an important factor in the bilateral relations. For example, in an article entitled 'Leaders of Kazakhstan and China Discussed Cooperation Issues', the newspaper asserted that the leaders of both countries 'very positively' assessed bilateral cooperation dynamics and perspectives (Kazakhstanskaia Pravda, 12.09.2014). In an earlier article, the paper reported that the Chinese leader expressed his admiration and support for the Conference on Interaction and Confidence-Building Measures in Asia, the Kazakhstan-backed foreign policy initiative that aims to create an Asian analogue of the Organization for Security and Cooperation in Europe (Kazakhstanskaia Pravda, 'China Admires Kazakhstan President's Political Strategic Vision', 21.05.2014). In yet another article, the newspaper reported a meeting between Xi Jinping and Nursultan Nazarbayev in May 2014, and mentioned that during that meeting several intergovernmental agreements, worth eight billion US dollars, were to be signed. The newspaper also praised the fact that the combined worth of all the Chinese economic projects in Kazakhstan, including direct investments, had reached forty-three billion US dollars in 2014 (Kazakhstanskaia Pravda, 19.05.2014, 'Nursultan Nazarbayev Will Have Talks with Xi Jinping'). Similarly, Egemen Qazaqstan, the Kazakh-language statebacked paper, reported that China and Kazakhstan will expand cooperation on energy issues, including oil and gas supplies from Western Kazakhstan to China, as well as enhance cooperation on the new energy sources research in connection with the upcoming EXPO-2017 to be held in Astana (Egemen Qazaqstan, 06.12.2014, 'Important Agreement Signed between Our Country and China').

Zhas Alash, the Kazakh-language newspaper that primarily focuses on the Kazakhspeaking Kazakhs' audience, generally experiences less governmental control and frequently adopts a more critical approach toward government policies, including foreign policy. In its discourse on China, Zhas Alash often takes fairly prejudiced and negative positions, even when describing political cooperation between the two countries. For example, in 'Chinese Dream Strategy of Nur-Otan Party', the paper criticized the government and the leadership of Nur-Otan, the ruling political party of Kazakhstan, for too closely replicating Chinese strategic documents and campaigns: 
Chinese leader's strategy called 'Chinese Dream' is similar to our country's strategy 'Kazakhstan-2050'. However, we do not want to see Bauyrzhan Baibek [one of the leaders of the NurOtan Party] to declare something like this tomorrow: "from now on we rename our Nur-Otan Party into the Chinese Communist Party Nur-Otan. Our strategies and goals are declared in the Xi Jinping's strategy 'Chinese Dream'. (Zhas Alash, 14.11.2013, 'Chinese Dream of Nur Otan Party'.)

Zhas Alash also demonstrates and employs general prejudices and suspicions toward China, even in contexts that do not directly involve Kazakhstan. In an article called 'Chinese Government Increased the Number of Spies to One Million', the paper described increased security measures in China's law enforcement system, and urged Kazakhstani citizens to use caution when visiting China since the 'street shoecleaners, newspaper vendors, parking attendants, ticket counter employees, and hotel concierges' there may all supply information to the Chinese security services, formally or informally (Zhas Alash, 03.06.2014, 'Chinese Government Increased Number of Spies to One Million').

Moreover, even fairly neutral and 'safe' government moves and actions often become the target of Zhas Alash criticism. In an article dedicated to the new intergovernmental agreement regarding mutual allocation of land in Astana and Beijing for construction of new embassy buildings, either for free or for symbolic lease payments, the newspaper expressed its concerns that a portion of the Kazakh land will be given up to China for forty-nine years (Zhas Alash, 30.10.2014, 'For Forty-Nine Years...'). In a similar manner, Zhas Alash advised the government to allocate more resources to both intelligence and academic research on China and Russia, as well as to create new research centers and think-tanks:

We think we know China and Russia pretty well. In reality, we know nothing about these countries. If such think-tanks would be working, maybe people from there could talk and fight with the Chinese expansion and Russian imperial ambitions [...] There are many Chinese here now [...] they marry Kazakh wives and pretend becoming Kazakhs. If one [of them] comes here legally, then five come without documents [...] (Zhas Alash, 'Welcoming China Means Giving Up Our Fathers' Tombs', 16.08.2013).

Only in rare instances does Zhas Alash take a softer approach toward China and the Kazakhstani-Chinese relationship in general, and, even when it does, it still operates with stereotypical clichés and graphic depictions. For example, in the article 'What 
Can Kazakhstan Achieve [Sitting] on the Dragon's Tail?', Zhas Alash demonstrated a more welcoming approach, stating that, due to all major intergovernmental agreements, Chinese-Kazakhstani relations are developing fairly well and economic cooperation is expanding; therefore, the Kazakhs' traditional fears of China, expressed in a folk proverb, 'Do not step on snake's tail' may no longer be applicable (Zhas Alash, 23.12.2014, 'What Can Kazakhstan Achieve [Sitting] on the Dragon's Tail?').

\section{Economic Cooperation with China}

Economic cooperation was primarily addressed in the state-owned papers, such as Kazakhstanskaia Pravda and Egemen Qazaqstan, and was also mostly presented in neutral-positive tones. Numerous articles focused on Khorgos, a large commercial and trade hub located at the Kazakhstan-China border, approximately 250 miles east of Almaty. Kazakhstan's leadership pays great attention to this project, and several cooperation initiatives have previously been launched to build a new set of trade facilities at that location. For example, in 'Around Khorgos There May Be a New Town', Kazakhstanskaia Pravda described the new Khorgos development project and quoted President Nazarbayev in his expression of hope that 'this long-awaited project, which we implement in cooperation with China, will increase trade between our countries' (Kazakhstanskaia Pravda, 25.12.2014).

Kazakhstanskaia Pravda also gave a detailed report of the Kazakhstan-China Business Council meeting, during which several economic agreements, worth fourteen billion US dollars, were signed. The Prime Minister of Kazakhstan, Karim Massimov, stated that the new Kazakhstan governmental strategy 'Nurly Zhol' [Radiate Path] matches well with the 'Silk Road Economic Belt' economic strategy of China, according to the newspaper. Chongqing, an industrial city and a logistical hub in China, appears to particularly benefit from these exchanges because of the new cargo and shipping routes going via Kazakhstan, which will allow for a significant decrease in cargo shipping times between Europe and China (Kazakhstanskaia Pravda, 26.12.2014, 'Bound by One Chain'). A few days previously, the newspaper reported meetings between Chinese and Kazakh businessmen, in which over 270 Chinese and 230 Kazakh companies participated. Several new agreements were signed, including those between Samruk-Qazyna Holding of Kazakhstan and several major Chinese corporations, including the China General Nuclear Power Corporation, 
the China International Water and Electric Corporation, the China International Trust and Investment Corporation, and the China National Petroleum Corporation (Kazakhstanskaia Pravda, 'Meeting with a Fourteen Billion Effect', 16.12.2014). This was also replicated in the Kazakh-language state-owned newspaper Egemen Qazaqstan; its article 'Important Agreement Signed between Our Country and China' focused on the energy cooperation, oil and gas supplies to China, and renewable energy research (Egemen Qazaqstan, 06.12.2014).

Interestingly, when narrating these talks, Russian-language Kazakhstanskaia Pravda also reported the Kazakhstan government's offer to their Chinese counterparts to move industrial production facilities, such as cement, glass, and agricultural production, to Kazakhstan (Kazakhstanskaia Pravda, 15.12.2014, 'China Moves Industrial Production to Kazakhstan'; 'PRC Ready to Open Construction and Agricultural Ventures in Kazakhstan', 15.12.2014). This is particularly interesting, as only a few years earlier in 2008-2009, the government of Kazakhstan leaked the fact that it was entering into negotiations with China with regard to leasing some portions of land in Eastern Kazakhstan to that nation for agricultural production, mainly soy, along with bringing thousands of Chinese agricultural workers to Kazakhstan. This led to a very hostile reaction across the political spectrum within Kazakhstan; certainly not expecting this effect, the government has quietly terminated the negotiations. As yet, it remains unclear as to whether many facilities will actually be moved to Kazakhstan, but this idea still appears to benefit from some political support among Kazakhstani government officials. The only major example of this type of economic cooperation briefly mentioned by Kazakhstanskaia Pravda was that of the opening of an assembly line in Qostanay, Northern Kazakhstan, by the Chinese car manufacturer Geely. The eventual goal of the venture was to reach a localization level of 50 per cent by 2017 (Kazakhstanskaia Pravda, 09.10.2014, 'Geely Chinese Cars Will Be Assembled in Kazakhstan').

\section{Chinese Tourists and Migrants to Kazakhstan}

Cooperation in the tourist industry left the media discourse more divided across linguistic realms, particularly with regard to the issue of Chinese tourists coming to Kazakhstan. Historical stereotypes and prejudices toward the Chinese were manifest in various news reports and commentaries. Russian-language papers followed up on the fact that the Kazakhstan government declared 2017 a year of Chinese tourism in 
Kazakhstan, with the hope of attracting up to five million Chinese people to visit the EXPO-2017 exhibition in Astana. However, this government initiative was met with criticism and hostility in the Kazakh discourse; the Zhas Alash article 'What If Chinese Came...', which demonstrates existing alarmist stereotypes concerning potential Chinese influx:

The government wants to attract up to five million Chinese tourists. Why don't they try to attract English or French tourists? [...] Of course, since China is way overpopulated, they advise its citizens to go and settle abroad. To let them all in would be a dangerous policy for us since many of them come on fake documents and remain unaccounted. [...] China's proposal to adopt visa-free travels for tourists is hence unacceptable for us. It is a way for them to conquer us without a war (Zhas Alash, 09.09.2014, 'What If Chinese Came').

The mutual visa regime between the two countries has existed since Kazakhstan's independence, and the visa application process has been criticized in both countries for long queues at the consulates, poor and uncomfortable waiting facilities, extended processing time for visa applications, complicated bureaucratic procedures, and a long list of documents that are required to be provided in support of visa applications, even for short-term visits. The governments of Kazakhstan and China held several rounds of negotiations around removing, or at least facilitating, the visa regime, beginning with group travels for tourist purposes; however, the very prospect of lifting visa requirements from Chinese citizens when entering Kazakhstan was met with concerns, even in Russian-language papers. The Vremya conducted a round of interviews with several prominent policy- and opinion-makers, journalists, and academics, including Murat Auezov, former ambassador of Kazakhstan to China, and the general tone of opinions regarding a lifting of the visa-regime with China ranged from fairly cautious to very negative. For example, Aidos Sarym, a prominent political activist, said:

Several dozen thousands of Kazakhstani citizens visit China every year, and a million of ethnic Kazakhs live in China and they have to go through the visa application process in order to come here... So, in principle, this [lifting visa requirements] is normal. There is, however, a big danger, that people with bad goals may come without visas claiming to be tourists. (Vremya, 10.08.2013, 'In Waiting Mode [on Visa-Free Regime]'. 
Murat Auezov, former Kazakh ambassador to China, expressed harsh criticism of this initiative, and implied that China has a governmental strategy of encouraging its citizens to go and settle abroad:

China is not a pet dog, it is a tiger! I argue that the visa regime should not only be there, but it should be purposefully very strict [...] In China, they regulate their migration - there is a special structure, which tries to put people from one province to one country, so that they could communicate and preserve their loyalty to China and their Chinese identity (Vremya, 10.08.2013, 'In Waiting Mode [on Visa-Free Regime]'.

Bulat Abilov, a prominent businessman and former politician, also questioned he government's estimates of the potential number of Chinese tourists traveling to Kazakhstan:

Someone [in the government] mentioned that five million Chinese tourists will visit Kazakhstan [in 2017]. I don't think this estimate is necessarily accurate, since during the entire last year only a few thousand Chinese tourists came. Why would they come here? To see Astana? They have dozens of cities like this, if not hundreds. When talking about visa regime, I think it makes more sense to lift it from citizens of the US and European countries, not necessarily from China (Vremya, 10.08.2013, 'In Waiting Mode [on Visa-Free Regime]'.

Furthermore, and related to tourism, the potential illegal migration, and infiltration, of Chinese citizens to Kazakhstan remains a prominent theme in the Kazakh-language papers. General concerns continue to be expressed regarding the potential, and growing, illegal immigration of Chinese citizens to Kazakhstan. These articles and editorial policies frequently express very stereotypical and, at times, even xenophobic, sentiments vis-à-vis the Chinese people. For example, in one article, 'How Many Chinese Are Hiding in Kazakhstan?', Zhas Alash criticized the government, the law enforcement agencies, and Vice Prime Minister Baqytzhan Sagintayev, personally, for the lack of a coherent and efficient policy for counting and tracking the Chinese visitors once they clear Kazakhstan's border control in airports and bus/train terminals (Zhas Alash, 15.05.2014). In another article, 'Mass Migration from China to Kazakhstan Exceeded 19,000 People [in 2014]', Zhas Alash reported that, of this number, approximately 13,000 came for 'private visits', around 300 came for 
'professional reasons' and also ended up marrying Kazakh women; 244 Chinese citizens moved and settled in Kazakhstan with their entire families. It is unclear from the article whether this number included ethnic Kazakhs who repatriated from China to Kazakhstan or ethnic Chinese (Han) (Zhas Alash, 04.11.2014, 'Mass Migration from China to Kazakhstan Exceeded 19,000 People [in 2014]'). What is clear is that the narrative towards the Chinese in Zhas Alash is negative.

Overall, we found that private newspapers have more coverage of the issue of Chinese citizens in Kazakhstan than public newspapers. Political and economic cooperation with China are mostly covered in public newspapers. This is due to the fact that public newspapers are the mouthpiece of the national policies of which the emphasis is on political and economic cooperation with Beijing. Also, economic cooperation with China is done through deals between huge corporations in both countries. Citizens in small and medium-sized businesses are not directly involved. Hence, citizens are prone to attend to issues with direct impact on their daily life, that is, the implication of Chinese visitors in, and migrants to their country. ${ }^{4}$

If one looks at the divides in Table 1 again, the difference between public and private newspapers actually implies that the private media can to a certain degree express and channel society's reaction to the government's efforts to form a more proChina discourse as revealed in public newspapers. This echoes the conceptual basis of this paper which stresses the role of the media in reflecting perceptions, prejudices and stereotypes in ethnically diverse societies.

The linguistic divide is more clearly seen between private newspapers of different languages (see Table 1). It is related to a much more important and deep cleavage in the modern Kazakhstani society. To put it simply, the shift from nomadic pastoralism (something that Kazakhs were doing for centuries) to a modern industrial society occurred in a very short time, basically within one generation. This led to a situation where modernity had its roots only in a small fraction of educated urban elite and Russian became associated with the modern path, whereas Kazakh was mostly preserved in the rural areas. Readers of private Kazakh-language and Russianlanguage newspapers have divergent views on what kind of state Kazakhstan should build and who owns the country. Kazakh-language newspapers tend to emphasize the exclusive "Kazakhness" of the state; they consider Kazakhs as exclusive legitimate owners of the state since Kazakhstan is the only place where Kazakhs can build a state. In contrast, Russian-language newspapers tend to talk about a "shared" notion 
of the state and its poly-ethnic character. It is fair to say that Russian-language newspapers have also developed stereotypical depiction of Kazakh-speaking Kazakhs as coming from remote rural areas, unfamiliar with modern technologies, lacking knowledge about global culture and history, and only concerned with praising glorious Kazakh heroes of the past. Given this context, it is not difficult to understand why China and the Chinese, as the 'others' are not perceived positively in Kazakh newspapers. Relatively speaking, Russian language newspapers can be more inclusive to 'the other' than Kazakh language newspapers as a result. This to some extent speaks to Syroezhkin's (2009) survey result which shows that Kazakhs are more negative towards Chinese migrants than Russians.

\section{Conclusion}

In recent years, academic momentum has been gathering with regard to measuring how people around the world view China (Aldrich, Lu, and Liu 2014; Chu, Kang, and Huang 2014; Kang and Chu 2014). Our analysis fills in the void of the Kazakhstani view on the issue, and it reveals that the Kazakhstani views toward China are, in fact, nuanced. The discourse in both state-sponsored Russian and Kazakh newspapers leans toward a positive stance on China, as it is the mouthpiece of national policies that increasingly support engagement with that country. However, in the private sphere, skepticism toward China is evident in Kazakh language newspapers and hidden in Russian language newspapers. Stereotypical images of China and its people, as well as sinophobia, are pervasive in private publications. Although most of these societal voices do not have a direct impact on changing Kazakhstan's national policies, they are important in the sense that the ruling elite must continue to gauge social views and to placate different stances in order to secure the stability and legitimacy of the regime. While this special issue in Ethnic and Racial Studies primarily focuses on ethnicities in China, our research contributes to the understanding of how the Chinese as a collectively imagined 'other' are being constructed, and even used for political purposes, in other countries.

\section{Note}


1. See "Vision and Actions on Jointly Building Silk Road Economic Belt and $21^{\text {st }}$ Century Maritime Silk Road” issued by China's National Development and Reform Commission, Ministry of Foreign Affairs, and Ministry of Commerce on March 2015, http://en.ndrc.gov.cn/newsrelease/201503/t20150330 669367.html (accessed 19 July 2015).

2. The ruling elites of Kazakhstan need legitimacy because of several reasons. To begin with, the ruling elites, led by Nursaltan Nazarbayev did not play a key role in ensuring Kazakhstan's independent statehood. Nazarbayev himself was actually not supportive of the dissolution of the Soviet Union. Hence, the ruling elites lack nationalist legitimacy to run the country. Second, the ruling elites are formed along traditional familial and kinship lines as well as economic and bureaucratic interests. The power is concentrated in the hands of the president, his family, a small group of oligarchs and technocrats. The government, accordingly, has relied on using economic development of the country to boost its legitimacy (i.e. "performance legitimacy"). The fear for potential Russian irredentism based on the clustering of Russian population in Northern Kazakhstan as well as unresolved territorial disputes with China pose great challenge for the ruling elites to convince its domestic constituents that they are able to maintain Kazakhstan's independent and sovereign statehood. For detailed discussion on the issue of legitimacy, please consult Clarke (2014) and Cummings (2006).

3. The media of the Soviet Union did not exist independently; in most cases, they were placed under the patronage of a Communist Party branch, a government agency, a giant industrial factory or a professional union. The most significant ones were usually administered under the various republics' Communist Party Central Committee and oblast-level newspapers reported to their respective oblast Party committees. These parent agencies usually provided all necessary funding, technological facilities, managed subscription and distribution channels, and even the cadres; therefore, the newspapers never had to worry about their finances, capital costs or supplies. Even though Soviet newspapers could receive income from advertisements (mostly in the late Soviet era), they almost never depended on the advertisements and subscription incomes in order to survive as they had guaranteed subsidies. In terms of general organizational structure, newspapers and magazines in the Soviet Union were put under strict control of the Communist Party and the 
security services since their major task was to spread ideological messages from the party and country leadership to the population. In this sense, the newspapers played a different role in Soviet society than in Western countries or even their predecessors in the Russian Empire; the Communist Party viewed their goal as not so much to inform the population about events and news as it was to create and shape interpretations of the events in compliance with Soviet ideology.

4. Issues of Xinjiang and Uyghurs which are supposed to be important in Kazakhstani-Chinese relations but did not appear often in the news article under analysis. Kazakhstani perceptions of Xinjiang is a close and yet distant place. It is close because there are Uyghurs who are culturally, linguistically and religiously connected to Kazakhs. The place is also distant because it is in China. However, despite the fact that Uyghurs are close the Kazakhs, the government of Kazakhstan opts for cooperation with China and had systematically arrested and transferred Uyghur activists to China. Because this is sensitive issue and is highly controlled by the government, it is not covered in the media.

\section{References}

Aldrich, John, Jie Lu, and Liu Kang. 2014. "How do Americans View the Rising China?" Journal of Contemporary China 24(92): 203-221.

Bremmer, Ian. 1994. "Nazarbaev and the North: State-Building and Ethnic Relations in Kazakhstan." Ethnic and Racial Studies 17(4): 619-635.

Brubaker, Rogers. 2011. "Nationalizing States Revisited: Projects and Processes of Nationalization in Post-Soviet States." Ethnic and Racial Studies 34(11): 1785-1814. Burkhanov, Aziz, and Dina Sharipova. 2014. “Kazakhstan’s Civic-National Identity:

Ambiguous Policies and Points of Resistance.” In Nationalism and Identity

Construction in Central Asia: Dimensions, Dynamics, and Directions, edited by

Mariya Y. Omelicheva, 21-36. London: Lexington Books.

Chen, Yu-Wen. 2015. "A Research Note on Central Asian Perspectives on the Rise of China: The Example of Kazakhstan." Issues and Studies 51(3).

Chen, Yu-Wen. 2014. The Uyghur Lobby: Global Networks, Coalitions and Strategies of the World Uyghur Congress. London: Routledge.

Cheng, Teng-Chi, and Szue-Chin Philip Hsu. 2005. "Between Power Balancing and Bandwagoning: Re-Thinking the Post-Cold War East Asia.” In Rethinking New 
International Order in East Asia: U.S., China, and Taiwan, edited by I Yuan, 425460. Taipei: Institute of International Relations and Center for China Studies, National Chengchi University.

Chu, Yun-Han, Liu Kang, and Min-Hua Huang. 2014. "How East Asians View the Rise of China." Journal of Contemporary China 24(93): 398-420.

Clarke, Michael. 2014. "Kazakh Responses to the Rise of China: Between Elite Bandwagoning and Societal Ambivalence?" In Asian Thought on China's Changing International Relations, edited by Niv Horesh and Emilian Kavalski, 141-172. Basingstoke: Palgrave Macmillan.

Clarke, Michael. 2011. Xinjiang and China's Rise in Central Asia-A History. London: Routledge.

Clarke, Michael. 2008. "China's Integration of Xinjiang with Central Asia: Securing a Silk Road to Great Power Status?" China and Eurasia Forum Quarterly 6(2): 89111.

Cummings, Sally N. 2006. "Legitimation and Identification in Kazakhstan." Nationalism and Ethnic Politics 12: 177-204.

Fierman, William. 1998. "Language and Identity in Kazakhstan: Formulations in Policy Documents 1987-1997." Communist and Post-Communist Studies 31 (2): 171-186.

Junisbai, Barbara. 2011. "Oligarchs and Ownership: The Role of Financial-Industrial Groups in Controlling Kazakhstan's 'Independent' Media." In After the Czars and Commissars: Journalism in Authoritarian Post-Soviet Central Asia, 35-57. Lansing, MI: Michigan State University Press.

Kang, David. 2009. "Between Balancing and Bandwagoning: South Korea's Response to China." Journal of East Asian Studies 9(1): 1-28.

Kuik, Cheng-Chwee. 2008. "The Essence of Hedging: Malaysia and Singapore's Response to a Rising China." Contemporary Southeast Asia 30(2): 159-185.

Liu, Kang, and Yun-Han Chu. 2014. “China's Rise through World Public Opinion: Editorial Introduction.” Journal of Contemporary China 24(92): 197-202.

Laclau, Ernesto; Mouffe, Chantal. 2001. Hegemony and Socialist Strategy: Towards a Radical Democratic Politics. London: Verso.

Laruelle, Marlene, and Sebastien Peyrouse. 2012. The Chinese Question in Central Asia: Domestic Order, Social Change and the Chinese Factor. London: Hurst 
\& Co.

Maxwell, McCombs, and Donald L. Shaw. 1972. "The Agenda-Setting Function of Mass Media.” Public Opinion Quarterly 36: 176-187.

MediaLaw Internews Project. 2010. The History of Formation of the Information Market in Kazakhstan. September 7, 2010. http://medialaw.asia/node/9139

Mearsheimer, John J. 2010. "The Gathering Storm: China's Challenge to US Power in Asia." The Chinese Journal of International Politics 3: 381-396.

Ministry of Information and Culture of Kazakhstan Statistics. 2012. http://blogs.egov.kz/kulmuhamed_m/questions/195323

O’Neill, Daniel C. 2014. "Risky Business: The Political Economy of Chinese Investment in Kazakhstan.” Journal of Eurasian Studies 5(2): 145-156.

Sadovskaya, Elena Y. 2007. "Chinese Migration to Kazakhstan: A Silk Road for Cooperation or a Thorny Road for Prejudice?" China and Eurasia Forum Quarterly 5(4): 147-170.

Schoen, Douglas E., and Melik Kaylan. 2014. The Russia-China Axis: The New Cold War and America's Crisis of Leadership. New York \& London: Encounter Books.

Shambaugh, David, and Michael Yahuda, eds. 2008. International Relations of Asia. Lanham: Rowman \& Littlefield Publishers.

Spehr, Scott, and Nargis Kassenova. 2012. "Kazakhstan: Constructing Identity in a Post- Soviet Society.” Asian Ethnicity 13(2): 135-151.

Surucu, Cengiz. 2005. Western in Form, Eastern in Content: Negotiating Time and Space in Post-Soviet Kazakhstan. The Oxford Society for the Caspian and Central Asia. TOSCCA Online Publications. http://www.toscca.co.uk/publications.htm Syroezhkin, Konstantin. 2014. Should Kazakhstan be Afraid of China: Myths and Phobias of Bilateral Relations. Almaty: Institute of World Economics and Politics under the Foundation of the First President of the Republic of Kazakhstan.

Syroezhkin, Konstantin. 2009. "Social Perceptions of China and the Chinese: A View from Kazakhstan.” Journal of Eurasian Studies 7(1): 29-46.

Wanta, Wayne, Guy Golan, and Cheolhan Lee. 2004. "Agenda Setting and International News: Media Influence on Public Perception.” Journalism and Mass Communication Quarterly 81 (2): 364-377.

Yemelianova, Galina M. 2014. "Islam, National Identity and Politics in Contemporary Kazakhstan.”Asian Ethnicity 15(3): 286-301. 
Ziegler, Charles E., and Menon Rajan. 2014. "Neomercantilism and Great-Power Energy Competition in Central Asia and the Caspian”. Strategic Studies Quarterly 8(2): 17-41.

Zardykhan, Zharmukhamed. 2004. "Russians in Kazakhstan and Demographic Change: Imperial Legacy and the Kazakh Way of National Building." Asian Ethnicity 5(1): 61-79.

Table 1. A typology of public discourse on China in Kazakhstan

\begin{tabular}{|l|l|l|}
\hline & $\begin{array}{l}\text { Russian language } \\
\text { newspapers }\end{array}$ & $\begin{array}{l}\text { Kazakh language } \\
\text { newspapers }\end{array}$ \\
\hline $\begin{array}{l}\text { Public (i.e., state- } \\
\text { sponsored) }\end{array}$ & $\begin{array}{l}\text { Positive } \\
\text { (Kazakhstanskaia Pravda) })\end{array}$ & $\begin{array}{l}\text { Positive } \\
\text { (Egemen Qazaqstan) }\end{array}$ \\
\hline Private & $\begin{array}{l}\text { Mixed views with inclination } \\
\text { toward hidden criticism of } \\
\text { China (Vremia) }\end{array}$ & $\begin{array}{l}\text { Critical and negative (Zhas } \\
\text { Alash) }\end{array}$ \\
\hline
\end{tabular}

Aziz Burkhanov is Assistant Professor in the Graduate School of Public Policy at Nazarbayev University.

ADDRESS: 53 Kabanbay Batyr Ave, Graduate School of Public Policy, Nazarbayev University, Astana, 010000, Republic of Kazakhstan.

Email: Aziz.Burkhanov@nu.edu.kz

Yu-Wen Chen (corresponding author) is Professor of Chinese Studies at the Department of World Cultures at the University of Helsinki and Hosting Professor at the Department of Asian Studies at Palacky University.

ADDRESS: P.O. Box 59, Department of World Cultures, FI-00014 University of Helsinki, Finland.

Email: Yu-Wen.Chen@upol.cz 